\title{
PENGARUH TAX AVOIDANCE DAN KOMISARIS INDEPENDEN TERHADAP COST OF DEBT DENGAN TRANSPARANSI PERUSAHAAN SEBAGAI VARIABEL MODERASI
}

\author{
Ba'diyatul Musrifa \\ Fakultas Ekonomi/ Program Studi Akuntansi, Universitas Sarjanawiyata Tamansiswa \\ E-mail: badiyatulmusrifa99@gmail.com
}

\begin{abstract}
This study aims to examine the effect of tax avoidance and independent commissioners on csot of debt with company transparency as a moderating variable. The sample used in this study is a manufacturing company listed on the Indonesia Stock Exchange (BEI) 2015-2019. Samples were taken using purposive sammpling and obtained 44 companies. This study uses multiple linear regression analysis and absolute difference test. The results of this study indicate that tax avoidance has a negative effect on cost of debt. Independent commissioner has no negative effect on cost of debt. Company transparency is able to weaken the negative effects of tax avoidance. Company transparency is able to weaken the negative influence of independent commissioners.
\end{abstract}

Keywords: Tax avoidance, independent commissioner, cost of debt, company transparency

\section{PENDAHULUAN}

\section{Latar Belakang}

Pertumbuhan ekonomi dalam Indonesia sangat berkembang pada dunia bisnis. Perkembangan dunia bisnis tidak lepas dari pendanaan yang diperoleh melalui utang ataupun modal. Utang tersebut dilakukan oleh perusahaan yaitu pendanaan yang berasal dari kreditor dan untuk perusahaan bunga dari surat utang usaha yang akan diberikan kepada kreditor menjadi cost of debt. Sumber pendanaan atau modal yang merupakan suatu hal yang sangat berpengaruh bagi setiap perusahaan, karena modal tersebut merupakan nyawa bagi setiap perushaan dan kegiatan operasional tidak akan berjalan dengan lancar tanpa adanya modal.

Fenomena yang terkait dengan Cost of debt yaitu yang dilakukan oleh PT. Delta Merlin Dunia Textile (DMDT) yang tidak berhati-hati dalam mengelola keuangan perusahaan dapat mengakibatkan kesulitan membayar utang sebesar Rp. 22,36 Triliun. Penurunan permintaan pasar, pertumbuhan pembayaran premi yang menurun karena ada kesalahan dalam menetapkan strategi keuangan. Kesalahan tersebut yaitu manajemen dalam menetapkan biaya investasi dan biaya operasional yang besar sementara pendapatan perusahaan cenderung fluktuatif yang mengakibatkan potensi bayar utang cukup besar (https://finance.detik.com/2019).

Peneliti mengambil tema mengenai cost of debt untuk diteliti karena perkembangan ekonomi di Indonesia tidak lepas dari pendanaan yang diperoleh memlalui utang atau modal. Dengan dilakukannya penelitian ini maka diharapkan dapat memberikan informasi mengenai resiko pada cost of debt tersebut berpengaruh dalam tax avoidance dan komisaris independen yang berkaitan dengan transparansi perusahaan. 
Penelitian ini merupakan pengembangan variabel yang dilakukan dari peneliti sebelumnya oleh Saputro, (2018). Perbedaan dari penelitian ini dengan peneliti sebelumnya adalah variabel yang digunakan oleh peneliti terdahulu yaitu tax avoidance sebagai variabel independen, cost of debt sebagai variabel dependen, dan transparansi perusahaan sebagai variabel moderasi. Sedangkan dalam penelitian ini, peneliti menambah variabel independen yaitu komisaris independen.

\section{Tujuan Penelitian}

Tujuan dari penlitian ini adalah untuk mengetahui apakah tax avoidance memiliki pengaruh negatif terhadap cost of debt, untuk mengetahui apakah komisaris independen memiliki pengaruh negatif terhadap cost of debt, untuk mengetahui apakah transparansi perusahaan dapat memperkuat pengaruh negatif tax avoidance terhadap cost of debt, untuk mengetahui apakah transparansi perusahaan dapat memperkuat pengaruh negatif komisaris independen terhadap cost of debt

\section{METODE PENELITIAN}

Penelitian ini merupakan penelitian kuantitatif. Data yang digunakan dalam penelitian ini merupakan data sekunder atau yang berbentuk angka. Sampel yang digunakan dalam penelitian ini adalah perusahaan manufaktur yang telah terdaftar di Bursa Efek Indonesia selama periode 2015-2019.

\section{Metode Pengambilan Sampel}

Populasi yang dipakai dalam penelitian ini adalah perusahaan manufaktur yang terdaftar di Bursa Efek Indonesia tahun 2015-2019. Pemilihan sampel pada penelitian ini menggunakan purposive sampling method dengan tujuan mendapatkan sampel yang representatif sesuai dengan kriteria yang ditentukan (Zahro, Afifudin, \& Mawardi, 2018). Adapun kriteria yang dibutuhkan dari perusahaan antara lain: (i) Perusahaan manufaktur yang terdaftar di Bursa Efek Indonesia selama periode 2015-2019. (ii) Perusahaan yang mempunyai laporan keuangan lengkap yang berakhir di 31 Desember dari tahun 2015-2019, untuk menjaga keseragaman analisis dan sampel. (iii) Perusahaan dengan laporan keuangan yang penyajiannya menggunakan mata uang rupiah, sehingga tidak terjadi perbedaan kurs yang terus berubah apabila disajikan dengan satuan mata uang yang lain. (iv) Perusahaan yang tidak sedang mengalami kerugian pada periode tahun 20152019. Karena perusahaan yang mengalami kerugian tidak melakukan penghindaran pajak. (v) Perusahaan yang melaporkan laporan keuangan sesuai data variabel yang di teliti selama periode penelitian 2015-2019

\section{Definisi Operasional dan Indikator Variabel}

\section{Cost Of Debt}

Cost of debt dapat diartikan sebagai tingkat yang harus diterima dari investasi guna untuk mencapai tingkat pengembalian (yield rate) yang dibutuhkan oleh kreditur atau tingkat pengembalian yang digunakan oleh kreditor saat melakukan pendaan pada perusahaan (Zahro, Afifudin, \& Mawardi, 2018). Cost of debt muncul karena disebabkan oleh perolehan utang yang dilakukan perushaan di masa lampau. utang sendiri yaitu kewajiban perusahaan untuk membayar beban bunga yang telah disepakati oleh pihak yang terkait dan kewajiban yang harus dibayar 
dimasa yang akan datang. Dalam penelitian ini cost of debt dihitung dengan membagi beban bunga dengan total utang berbunga

Rumus yang digunakan sebagai berikut :

$$
\mathrm{COD}=\frac{\text { Beban Bunga }}{\text { Rata-rata utang jangka panjang dan jangka pendek }}
$$

\section{Tax Avoidance}

Tax avoidance adalah susunan dari tax planning secara ekonomis yang berusaha untuk memaksimalkan penghasilan setelah pajak dengan upaya mengefisiensikan beban pajak tetapi tidak melanggar aturan pajak yaitu dengan memanfaatkan celah-celah yang ada dalam undangundang perpajakan. Tax avoidance dalam penelitian ini diukur dengan pendekatan Cash Effective Tax Rate (CASH ETR), mengikuti perhitungan yang dilakukan oleh (Saputro, 2018) yaitu pembayaran pajak dibagi laba sebelum pajak

Rumus yang digunakan sebagai berikut :

$$
\text { CETR }=\frac{\text { Pembayaran Pajak }}{\text { Laba sebelum pajak }}
$$

\section{Komisaris Independen}

Komisaris Independen merupakan organisasi perusahaan yang bertugas memiliki tanggung jawab dan kewenangan penuh atas pengurusan perusahaan serta memberikan nasihat kepada direksi guna untuk memastikan bahwa perusahaan telah melaksanakan Good Coorporate Governance. Fungsi komisaris independen yang termasuk di dalamnya yaitu ; melakukan pemberhentian direksi untuk singkat waktu yang diperlukan serta untuk memberikan nasihat kepada direksi. Komisaris independen dapat diukur dengan proporsi dewan komisaris independen terhadap total dewan komisaris (Gita Fitri Anggini, Samin, 2018). Perhitungan komisaris independen dapat dirumuskan sebagai berikut :

$$
\text { Proporsi DKI }=\frac{\sum \text { Anggota } D K I}{\sum \text { Seluruh anggota } D K} \times 100 \%
$$

\section{Transparansi Perusahaan}

Transparansi perusahaan merupakan ketersediaan informasi tentang perusahaan untuk investor atau masyarakat yang berfungsi sebagai tata kelola perusahaan guna mengurangi konflik kepentingan antara manajemen dengan pemegang saham. Pengukuran transparansi informasi menggunakan di proksikan pada Voluntary Disclosure ( Pengungkapan Sukarela). (Pradnyana \& Noviari, 2017). Semakin tinggi indeks pengungkapan, maka semakin tinggi kualitas pengungkapan informasi perusahaan

Perhitungan untuk mencari angka pada indeks yang ditentukan dengan rumus sebagai berikut

$$
\mathrm{CSRJ}_{\mathrm{i}}=\frac{\sum x y_{i}}{n_{i}}
$$




\section{Pengujian Hipotesis}

Penelitian ini melibatkan empat variabel yaitu dua variabel independen, satu variabel dependen dan satu variabel moderasi. Variabel independen yaitu tax avoidance dan komisaris audit, variabel dependen yaitu cost of debt, dan variabel yaitu moderasi transparansi perusahaan. Pengujian hipotesis dalam penelitian ini menggunkan analisis regresi linear berganda dan untuk variabel moderasi menggunakan Uji Selisih Mutlak.

\section{a. Analisis Regresi Linier Berganda}

Adapun dalam persamaan analisis regresi linier berganda dengan persamaan linier sebagai berikut :

$$
\mathrm{Y}=\alpha+\beta_{1} \mathrm{X}_{1}+\beta_{2} \mathrm{X}_{2}+\varepsilon
$$

\section{b. Uji Selisih Mutlak}

Adapun dalam analisis regresi untuk variabel moderasi yaitu dengan Uji Selisih Mutlak yaitu dengan persamaan linier sebagai berikut:

$$
\begin{aligned}
& Y=\alpha_{0}+\beta_{1} X_{1}+\beta_{3} X_{3}+\beta_{4}\left(X_{1}-X_{3}\right)+\varepsilon \\
& Y=\alpha_{0}+\beta_{2} X_{2}+\beta_{3} X_{3}+\beta_{5}\left(X_{2}-X_{3}\right)+\varepsilon
\end{aligned}
$$

\section{c. Uji Koefisien Determinasi $\left(\mathbf{R}^{2}\right)$}

Koefisien determinasi (R2) pada dasarnya menyangkut seberapa jauh kemampuan model dalam menerangkan macam variabel dependen. Nilai koefisien determinasi yaitu antara nol dan satu. Nilai $\mathrm{R}^{2}$ yang kecil sama dengan kemampuan variabel-variabel independen dalam menjelaskan macam variabel dependen yang terbatas. Kelemahan mendasar penggunaan koefisien determinasi yaitu bisa terhadap jumlah variabel dependen yang dimasukkan ke dalam model. Karena dalam penelitian ini menggunakan banyak variabel independen, maka nilai adjusted R2 lebih tepat digunakan untuk mengukur seberapa jauh kemampuan model dalam menerangkan variasi variabel dependen (Ghozali, 2018).

\section{d. Uji Signifikan Simultan (Uji F)}

Uji Signifikan Simultan (Uji F) digunakan untuk menguji kecocokan model yang digunakan untuk mengukur ketepatan fungsi regresi sampel dalam menaksir nilai aktual (Ghozali, 2018). Pengujian ini menggunakan tingkat signifikansi 0,05, dengan kriteria bila $\mathrm{F}$ hitung $>\mathrm{F}$ tabel dan tingkat signifikansi $\leq 0,05$, maka Ho yang menyatakan bahwa semua variabel independen tidak berpengaruh secara simultan terhadap variabel dependen, ditolak. Artinya secara simultan semua variabel independen berpengaruh terhadap variabel dependen. Jika $\mathrm{F}$ hitung $<\mathrm{F}$ tabel dan tingkat signifikansi $\geq 0,05$, maka Ho diterima, yang berarti secara simultan semua variabel independen tidak berpengaruh signifikan terhadap variabel dependen.

\section{e. Uji Signifikansi Parameter Individual (Uji T)}

Uji Signifikan Simultan (Uji F) digunakan untuk menguji kecocokan model yang digunakan untuk mengukur ketepatan fungsi regresi sampel dalam menaksir nilai aktual (Ghozali, 2018). Pengujian ini menggunakan tingkat signifikansi 0,05, dengan kriteria pengambilan keputusan bila $\mathrm{F}$ hitung $>\mathrm{F}$ tabel dan tingkat signifikansi $\leq 0,05$, maka Ho yang menyatakan bahwa semua variabel independen tidak berpengaruh secara simultan terhadap variabel dependen, ditolak. Artinya secara simultan semua variabel independen 
berpengaruh terhadap variabel dependen. Jika $\mathrm{F}$ hitung $<\mathrm{F}$ tabel dan tingkat signifikansi $\geq$ 0,05 , maka Ho diterima, yang berarti secara simultan semua variabel independen tidak berpengaruh signifikan terhadap variabel dependen.

\section{HASIL DAN PEMBAHASAN}

\subsection{Hasil Penelitian}

Data yang digunakan sebagai populasi dalam penelitian ini adalah perusahaan-perusahaan manufaktur yang telah go-public dan tercatat di Bursa Efek Indonesia. Sampel yang digunakan dalam penelitian ini adalah laporan keuangan tahunan perusahaan manufaktur pada tahun 20152019. Jumlah perusahaan manufaktur yang dijadikan sebagai penelitian sebanyak 44 perusahaan dan total laporan tahunan yang akan di telusuri dalam penelitian ini sebanyak 220 laporan tahunan. Pertimbangan dalam pemilihan sampel pada umumnya disesuaikan dengan tujuan atau masalah penelitian.

Tabel 1 dibawah ini menyajikan proses seleksi sampel berdasarkan kriteria yang telah ditetapkan dalam penelitian ini.

Tabel 1 Data Pemilihan Sampel

\begin{tabular}{|c|l|c|}
\hline No & \multicolumn{1}{|c|}{ Kriteria } & Jumlah \\
\hline 1. & $\begin{array}{l}\text { Perusahaan manufaktur yang terdaftar dii Bursa } \\
\text { Efek Indonesia pada tahun 2015-2019 }\end{array}$ & 135 \\
\hline 2. & $\begin{array}{l}\text { Perusahaan yang tidak memiliki data lengkap } \\
\text { terkait informasi yang dibutuhkan untuk } \\
\text { menganalisis data }\end{array}$ & $(27)$ \\
\hline 3. & $\begin{array}{l}\text { Perusahaan yang menyajikan laporan keuangan } \\
\text { dalam mata uang asing }\end{array}$ & $(21)$ \\
\hline 4. & $\begin{array}{l}\text { Perusahaan manufaktur yang mengalami } \\
\text { kerugian pada tahun 2015-2019 }\end{array}$ & $(39)$ \\
\hline 5. & Jumlah perusahaan yang memenuhi kriteria & 44 \\
\hline & Periode pengamatan 5x44 & 220 \\
\hline & Data Outlier & $(66)$ \\
\hline & Jumlah Sampel & 154 \\
\hline
\end{tabular}

\section{Statistik Deskriptif}

Tabel 2. Hasil Uji Statistik Deskriptif

\begin{tabular}{|l|r|r|r|r|r|}
\hline & $\mathrm{N}$ & Minimum & Maximum & Mean & $\begin{array}{c}\text { Std. } \\
\text { Deviation }\end{array}$ \\
\hline Cost of debt & 154 &, 001 &, 150 &, 05542 &, 041443 \\
\hline Tax Avoidance & 154 &, 152 &, 476 &, 28555 &, 079822 \\
\hline $\begin{array}{l}\text { Komisaris } \\
\text { independen }\end{array}$ & 154 &, 200 &, 800 &, 41379 &, 104904 \\
\hline $\begin{array}{l}\text { Transparansi } \\
\text { Perusahaan }\end{array}$ & 154 &, 022 &, 253 &, 13271 &, 048165 \\
\hline $\begin{array}{l}\text { Valid N } \\
\text { (listwise) }\end{array}$ & 154 & & & & \\
\hline Sumber : Data sekunder, 2020, diolah & & & \\
\hline
\end{tabular}




\section{Hasil Uji Analisis Regresi Linier Berganda}

Tabel 3. Hasil Uji Signifikansi Parameter Individual (Uji T)

\begin{tabular}{|c|c|c|c|c|c|}
\hline \multirow[b]{2}{*}{ Model } & \multicolumn{2}{|c|}{$\begin{array}{c}\text { Unstandardized } \\
\text { Coefficients }\end{array}$} & \multirow{2}{*}{$\begin{array}{c}\begin{array}{c}\text { Standardized } \\
\text { Coefficients }\end{array} \\
\text { Beta }\end{array}$} & \multirow[b]{2}{*}{$\mathrm{t}$} & \multirow[b]{2}{*}{ Sig. } \\
\hline & B & $\begin{array}{l}\text { Std. } \\
\text { Error }\end{array}$ & & & \\
\hline 1 (Constant $)$ & ,019 & ,018 & & 1,018 & 3,310 \\
\hline $\begin{array}{l}\text { Tax } \\
\text { Avoidance }\end{array}$ & , 109 & ,041 & ,210 & 2,632 & ,009 \\
\hline $\begin{array}{l}\text { Komisaris } \\
\text { Independen }\end{array}$ & 013 & ,031 & ,034 & ,425 & 671 \\
\hline
\end{tabular}

a. Dependent Variable: Cost Of Debt

Sumber : Data sekunder, 2020, diolah

Berdasarkan tabel 3 diatas terlihat bahwa variabel CETR memiliki pengaruh positif terhadap cost of debt atau tax avoidance berpengaruh negatif terhadap cost of debt pada tingkat signifikan 5\%. CETR memiliki probabilitas sebesar 0,009 <0,05 dengan koefisien 0,109. Dapat disimpulkan bahwa hipotesis yang menyatakan CETR berpengaruh positif terhadap cost of debt atau tax avoidance berpengaruh negatif terhadap cost of debt dapat diterima.

Komisaris independen memilki probabilitas 0,671>0,05 dengan koefisien 0,013. Berdasarkan nilai probabilitas tersebut menunjukkan bahwa komisaris independen tidak terdapat pengaruh terhadap cost of debt. Hipotesis yang menyatakan komisaris independen berpengeruh negatif terhadap cost of debt di tolak.

\section{Hasil Uji Nilai Selisih Mutlak}

\section{1) Pengujian Nilai Selisih Mutlak Persamaan 1}

Tabel 4. Uji Signifikansi Parameter Individual (Uji T)

\begin{tabular}{|c|c|c|c|c|c|}
\hline \multirow[b]{2}{*}{ Model } & \multicolumn{2}{|c|}{$\begin{array}{c}\text { Unstandardized } \\
\text { Coefficients }\end{array}$} & \multirow{2}{*}{$\begin{array}{c}\text { Standardized } \\
\text { Coefficients } \\
\text { Beta }\end{array}$} & \multirow[b]{2}{*}{$t$} & \multirow[b]{2}{*}{ Sig. } \\
\hline & B & $\begin{array}{c}\text { Std. } \\
\text { Error }\end{array}$ & & & \\
\hline \multirow{4}{*}{$\begin{array}{ll}1 & \text { (Constant) } \\
& \text { Zscore(Tax } \\
& \text { avoidance) } \\
& \text { Zscore(Transparansi } \\
& \text { perusahaan) } \\
& \text { MODERASI1 }\end{array}$} & ,059 & ,006 & & 10,656 & ,000 \\
\hline & ,009 & ,003 & ,213 & 2,684 & ,008 \\
\hline &,- 006 & ,003 &,- 147 & $-1,847$ & ,067 \\
\hline &,- 003 & ,004 &,- 071 &,- 887 & ,376 \\
\hline
\end{tabular}

a. Dependent Variable: Cost of debt

Sumber : Data sekunder, diolah, 2020 
Hasil tabel diatas menunjukkan bahwa secara individu variabel Ztax avoidance nilai koefisien 0,009 dengan probabilitas signifikansi 0,008. Variabel Ztransparansi perusahaan nilai koefisien -0,006 dengan probabilitas signifikansi 0,067 . Variabel moderasi MODERASI1 memiliki nilai 0,376 lebih dari 0,05, sehingga hipotesis 3 yang menyatakan bahwa transparansi perusahaan dapat memperkuat pengaruh negatif tax avoidance terhadap cost of debt di tolak.

\section{2) Pengujian Nilai Selisih Mutlak Persamaan 2}

Tabel 5. Uji Signifikansi Parameter Individual (Uji T)

\begin{tabular}{|c|c|c|c|c|c|}
\hline \multirow[b]{2}{*}{ Model } & \multicolumn{2}{|c|}{$\begin{array}{l}\text { Unstandardized } \\
\text { Coefficients }\end{array}$} & \multirow{2}{*}{$\begin{array}{c}\text { Standardized } \\
\text { Coefficients } \\
\text { Beta }\end{array}$} & \multirow[b]{2}{*}{$t$} & \multirow[b]{2}{*}{ Sig. } \\
\hline & B & $\begin{array}{l}\text { Std. } \\
\text { Error }\end{array}$ & & & \\
\hline 1 (Constant) & ,062 & ,006 & & 10,444 & $\overline{, 000}$ \\
\hline $\begin{array}{l}\text { Zscore(Komisaris } \\
\text { Independen) }\end{array}$ & ,004 & ,004 & ,098 & 1,125 & ,262 \\
\hline $\begin{array}{l}\text { Zscore(Transparansi } \\
\text { perusahaan) }\end{array}$ &,- 007 & ,003 &,- 176 & $-2,156$ & 033 \\
\hline MODERASI2 &,- 007 & ,005 &,- 119 & $-1,391$ & , 166 \\
\hline
\end{tabular}

a. Dependent Variable: Cost Of Debt

Sumber : Data sekunder, diolah, 2020

Berdasarkan tabel 4.16 hasil uji selisih mutlak menunjukkan bahwa secara individu variabel Zkomisaris independen memberikan nilai koefisien 0,004 dengan probabilitas signifikansi 0,262. Variabel Ztransparansi perusahaan nilai koefisien $-0,007$ dengan probabilitas signifikansi 0,033. Variabel moderasi MODERASI2 memiliki nilai 0,166 lebih dari 0,05, sehingga hipotesis 4 yang menyatakan bahwa transparansi perusahaan dapat memperkuat pengaruh negatif komisaris independen terhadap cost of debt tidak dapat di terima.

\subsection{Pembahasan}

\section{Pengaruh Tax Avoidance terhadap Cost of debt}

Hasil pengolahan data yang telah dilakukan, dapat diketahui hasil pengujian hipotesis untuk membuktikan pengaruh tax avoidance terhadap cost of debt yang dilakukan dengan pengujian statistik. Berdasarkan hasil penelitian tersebut menunjukkan bahwa CETR berpengaruh positif atau tax avoidance berpengaruh negatif terhadap cost of debt dan hipotesis pertama yang menyatakan bahwa tax avoidance berpengaruh negatif terhadap cost of debt dapat diterima.

Perusahaan menggunakan hutang lebih banyak ketika terlibat dalam tax avoidance (penghindaran pajak). Dari pihak eksternal yang berupa hutang hal tersebut dapat mempengaruhi struktur modal saham dan laba ditahan. Tax avoidance bersifat substitusi terhadap biaya hutang yaitu dimana perusahaan menggunakan utang lebih sedikit ketika mereka melakukan penghindaran pajak. Hal tersebut dapat diperkuat dalam teori trade of, karena tax avoidance dapat menurunkan cost of debt dengan adanya hal tersebut apabila perusahaan akan menggunakan penghindaran pajak dan biaya hutang lebih tinggi maka akan berakibat denda pada pajak dan reputasi perusahaan akan buruk secara publik. 


\section{Pengaruh Komisaris Independen terhadap Cost of debt}

Hasil pengujian hipotesis ini dilakukan untuk membuktikan pengaruh komisaris independen terhadap cost of debt yang dilakukan dengan pengujian statistik. Dari hasil regresi menunjukkan bahwa komisaris independen tidak terdapat pengaruh terhadap cost of debt. Berdasarkan nilai probabilitas tersebut menunjukkan bahwa hipotesis yang menyatakan komisaris independen berpengeruh negatif terhadap cost of debt di tolak.

Hal tersebut sesuai dengan teori keagenan yang mengungkapkan bahwa agen memiliki lebih banyak informasi dibandingkan pemilik yang lebih sedikit memiliki informasi. Informasi asimetri akan menimbulkan biaya agensi, munculnya komisaris independen disebabkan adanya konflik keagenan, komisaris yang tinggi menimbulkan agency cost. Dalam struktur organisasi adanya proporsi dewan komisaris independen perusahaan dapat menyediakan laporan keuangan yang lebih berintegritas sehingga kreditur dapat melihat kinerja di dalam suatu perusahaan yang akhirnya akan mempengaruhi cost of debt atau tingkat pengembalian yang sudah ditetapkan oleh pihak kreditur.

\section{Transparansi Perusahaan dapat Memperkuat Pengaruh Negatif Tax Avoidance terhadap Cost Of Debt}

Hipotesis yang menyatakan bahwa transparansi perusahaan dapat memperkuat pengaruh negatif tax avoidance terhadap cost of debt tidak terbukti. Transparansi perusahaan tidak dapat memoderasi hubungan antara tax avoidance terhadap cost of debt. Transparansi perusahaan yang luas maka akan merubah pendapat publik mengenai perusahaan yang melakukan tax avoidance dengan transparansi perusahaan maka akan lebih meningkatkan nilai perusahaan.

Dalam penelitian ini tidak berpengaruhnya transparansi perusahaan pada hubungan tax avoidance terhadap cost of debt dapat disebabkan bahwa semakin tidak transparan pada perusahaan - perusahaan manufaktur yang melakukan aktivitas penghindaran pajak, maka biaya hutang akan semakin tinggi. Hal ini disebabkan karena tidak adanya peran dari sistem transparansi perusahaan yang tidak dapat membatasi perilaku manajemen dalam melakukan perilaku tax avoidance, aktivitas penghindaran pajak yang hanya dilakukan sebagai efisiensi pajak.

\section{Transparansi Perusahaan dapat Memperkuat Pengaruh Negatif Komisaris Independen terhadap Cost Of Debt}

Hipotesis yang menyatakan transparansi perusahaan dapat memperkuat pengaruh negatif komisaris independen terhadap cost of debt tidak terbukti. Jadi transparansi perusahaan tidak dapat memoderasi hubungan antara komisaris independen terhadap cost of debt. Hal ini menunjukkan bahwa transparansi perusahaan tidak membantu komisaris independen dalam mengurangi cost of debt. Semakin tinggi transparansi perusahaan dan komisaris independen maka akan semakin rendah biaya hutang perusahaan.

Dalam penelitian ini tidak berpengaruhnya transparansi perusahaan pada hubungan komisaris independen terhadap cost of debt disebabkan karena transparansi perusahaan yang dibentuk untuk membentuk komisaris independen dalam melakukan monitoring pada proses pelaporan keuangan menunjukkan bahwa jumlah komisaris independen yang semakin meningkat dalam perusahaan hanya untuk melaksanakan peraturan, sehingga jumlah komisaris independen yang semakin meningkat dalam perusahaan tidak dapat mempengaruhi jumlah pengungkapan pada transparansi perusahaan. 


\section{KESIMPULAN}

Berdasarkan hasil analisis data dan pembahasan yang telah dilakukan maka dapat diambil kesimpulan untuk variabel tax avoidance memiliki pengaruh negatif terhadap cost of debt atau CETR berpengaruh positif terhadap cost of debt. Hasil penelitian yang mendukung oleh Sherly \& Fitria, (2019) dan Saputro, (2018) yang menyatakan bahwa tax avoidance berpengaruh negatif terhadap cost of debt. Hasil penelitian tersebut mengungkapkan bahwa semakin besar penghindaran pajak maka akan semakin mengurangi biaya hutang. Variabel komisaris independen tidak berpengaruh negatif terhadap cost of debt. Hasil penelitian yang mendukung oleh Calen, (2019), Romadani, (2019), dan Zahro, Afifudin, \& Mawardi, (2018) yang menyatakan bahwa komisaris independen tidak memiliki pengaruh terhadap cost of debt. Variabel transparansi perusahaan tidak dapat memoderasi pengaruh negatif antara tax avoidance terhadap cost of debt. Variabel transparansi perusahaan tidak dapat memoderasi pengaruh negatif antara komisaris independen terhadap cost of debt.

\section{Saran}

Berdasarkan hasil penelitian dan pembahasan sebelumnya dapat ditarik beberapa saran sebagai berikut:

1) Untuk penelitian selanjutnya bisa meneliti dengan mengubah atau menambah variabel independen yang mungkin berpengaruh terhadap cost of debt sehingga memungkinkan untuk mendapatkan hasil penelitian yang lebih baik dalam menjelaskan variasi variabel, seperti voluntary disclosure, kinerja keuangan, dan ukuran perusahaan.

2) Peneliti selanjutnya dapat meneliti dengan objek penelitian yang berbeda misalnya di sektor pertambangan, sektor perbankan, property dan real estate atau jenis sektor lainnya yang terdaftar di Bursa Efek Indonesia.

3) Peneliti selanjutnya diharapkan dapat menambah jangka waktu pelitian lebih dari lima tahun sehingga dapat lebih memperlihatkan kondisi perusahaan yang sebenarnya.

\section{DAFTAR PUSTAKA}

Calen. (2019). PENGARUH GOOD CORPORATE GOVERNANCE TERHADAP COST OF DEBT PADA PERUSAHAAN RETAIL YANG TERDAFTAR DI BURSA EFEK INDONESIA. 2.

Ghozali, I. (2018). Aplikasi Analisis Multivariante Dengan Program IBM SPSS 25 (9th ed.). Badan Penerbit Universitas Diponegoro.

Gita Fitri Anggini, Samin, S. Y. W. (2018). Pengaruh Cooporate Coporate Governance terhadap biaya utang. Pengaruh Cooporate Coporate Governance Terhadap Biaya Utang, 2, 227-249.

Pradnyana, \& Noviari. (2017). Pengaruh Perencanaan Pajak Terhadap Nilai Perusahaan Dengan Transparansi Perusahaan Sebagai Variabel Moderasi. Jurnal Akuntansi, 3(2), 1-13.

Romadani. (2019). PENGARUH PENGHINDARAN PAJAK DAN GOOD CORPORATE GOVERNANCE TERHADAP COST OF DEBT : STUDI EMPIRIS PADA PERUSAHAAN DI INDONESIA.

Saputro. (2018). PENGARUH TAX AVOIDANCE TERHADAP BIAYA UTANG (COST OF DEBT) DENGAN TRANSPARANSI PERUSAHAAN SEBAGAI VARIABEL MODERATING. (2). https://doi.org/10.20961/ge.v4i1.19180 
Sherly, E. N., \& Fitria, D. (2019). PENGARUH PENGHINDARAN PAJAK, KEPEMILIKAN INSTITUSIONAL, DAN PROFITABILITAS TERHADAP BIAYA HUTANG (Studi Empiris Pada Perusahaan Manufaktur Yang Terdaftar Di BEI Periode 2011-2015). EKOMBIS REVIEW: Jurnal Ilmiah Ekonomi Dan Bisnis, 7(1), 58-69. https://doi.org/10.37676/ekombis.v7i1.701

Zahro, F., Afifudin, \& Mawardi, M. C. (2018). Pengaruh Penghindaran Pajak Dan Good Corporate Governance Terhadap Cost of Debt. Molecular Cancer, 7(6), 62-76.

https://doi.org/10.1186/1476-4598-10-45

https://finance.detik.com/2019 